Article

\title{
Assessment of Used Baby Diapers Composting in Bolivia
}

\author{
Navarro Ferronato ${ }^{1, *(\mathbb{D})}$, Máximo Lucio Nova Pinedo ${ }^{2}$ and Vincenzo Torretta ${ }^{1}$ (i) \\ 1 Department of Theoretical and Applied Sciences, University of Insubria, Via G.B Vico 46, 21100 Varese, Italy; \\ vincenzo.torretta@uninsubria.it \\ 2 Department of Agronomic Engineering, Catholic University of Carmen Pampa, Coroico, Bolivia; \\ maxcasanova100@gmail.com \\ * Correspondence: nferronato@uninsubria.it
}

Received: 25 May 2020; Accepted: 19 June 2020; Published: 21 June 2020

check for updates

\begin{abstract}
Solid waste open dumping in developing countries is a global concern. To move towards sustainable development, mixed waste should be reduced, and recyclable waste recovered. The aim of the current research was to find appropriate solutions to disposable used baby-diapers recycling in Bolivia since it is a waste fraction widely produced and commonly disposed of in open dumps. Composting of the organic diaper hydrogel was assessed in five trials, adding components available locally: cow dung, activated bacteria, and Californian red earthworms (Eisenia fetida). It was observed that about 60 days were globally required for biomass decomposition with cow dung, activated bacteria, and earthworms, and more than 70 days for the treatment of the substrate mixed only with manure, while the diaper hydrogel did not degrade without cow dung. This research is the first that attempted to treat disposable used baby diapers with the vermicomposting process. In general, the outcomes of the research are promising: vermicomposting with cow manure can be a recycling option for disposable used baby diapers, introducing appropriate practices toward a circular economy in developing regions.
\end{abstract}

Keywords: solid waste management; developing countries; Latin America; selective collection; recycling; biomass valorization; vermicomposting; cow dung; circular economy; sustainable development

\section{Introduction}

Waste mismanagement represents a global issue [1,2], and solid waste management (SWM) is still an environmental, economic, and social issue in the 21st century [3]. Zero waste is a utopia, and solutions should be found in the short term in both developed and developing countries [4]. Global responses must be identified to reduce greenhouse gas emissions due to SWM [5] since, in 2018, 2010 million tons of municipal solid waste (MSW) were generated all around the world, estimating that these quantities might increase to 3400 million tons by 2050 [6]. Out of 17 Sustainable Development Goals (SDGs) of the 2030 Agenda for Sustainable Development, at least 12 SDGs have a direct link to SWM [7]. Therefore, SWM must be a priority for policy-makers, scholars, engineers, and international associations [8].

After collection, MSW organic waste should be valorized, while recyclable materials recovered [9]. However, the remaining waste (composed of unrecyclable residues), generally and virtually consisting of about $20-25 \mathrm{wt} \%$ of the total, would go to final disposal sites (i.e., sanitary landfills) [10]. These mixed and unrecoverable waste amounts could be used for energy recovery, although it is not still a widespread methodology in the developing world [11]. Therefore, in developing regions, the aim is to reduce these garbage fractions or recover them by other waste-treatment technologies [12], better if appropriated 
for the local context. A waste fraction abundant in mixed and unrecyclable portions, and usually not valorized, is disposable baby diapers. In developing countries, they are typically disposed of in sanitary landfills or in open dumpsites [13,14], although these residues have potentialities to be recovered [15].

Disposable diapers contain synthetic polymers (i.e., superabsorbent polymer) and natural ones. The main component is cellulose pulp (on average $35 \mathrm{wt} \%$ of the diaper) [16]. In order to be recovered, used baby diapers (UBDs) must be collected separately at the source and transported to dedicated facilities that allow selecting plastics and the biodegradable fractions [17]. Therefore, separate collection and appropriate treatment technologies can support the increase of the recycling rate and the reduction of waste disposed of into sanitary landfills. In developed countries, these practices can be implemented, while developing countries suffer a lack of technologies and reliable solutions for their application $[18,19]$.

In 2016, Bolivia generated approximately 2 million tons of MSW per year, the equivalent of 5400 tons per day, with 70\% exclusively coming from the 10 megacities of the country [20], which also happens in other Latin America's countries like Colombia [21], Ecuador [22], and Mexico [23]. In addition, the demand for disposable baby diapers has increased over the years, showing an increase in sales volumes from 17.18 million in 2012 to 26.80 million in 2016. In Bolivia, most of the used diapers are disposed of in open dumps, which finally fall into water bodies [24].

The objective of the research presented in this article was to suggest a solution appropriate for the context and able to recycle disposable UBDs. The implementation of innovative recycling options can support the reduction of uncontrolled disposal of mixed waste and the introduction of a new economy based on waste-recycling options. Therefore, the aim of the paper is to present the findings of the research conducted in Bolivia based on the objective already mentioned and discuss possible future applications that can be employed in the poor areas of the global South.

Other studies have been conducted at the international level in order to find solutions to the UBD disposal. Some scholars suggested using the superabsorbent polymer recovered from waste baby diapers for increasing water retention in soil and improving irrigation management [25]. Other researchers explored the applicability of shredded waste diapers as an innovative viscosity-modifying admixture for cement grouts and concrete [26]. More conventional studies analyzed the biological treatment of UBDs after selective collection. For example, a full-scale composting of door-to-door collected organic waste with a $3 \mathrm{wt} \%$ of compostable diapers was conducted, finding good results in terms of compost production [16,27]. Other studies reported that edible mushrooms mixed with UBDs and gardening waste can be implemented as an attractive treatment alternative for urban organic waste [28]. Similarly, other authors conducted research for assessing the feasibility of composting UBDs along with grass and dry and fresh leaves, providing positive results [29]. Finally, other solutions described in the scientific literature might be the microwave pyrolysis, which has a great prospect in transforming UBDs into liquid oil and char products [30]; or the use of recycled pulp and superabsorbent polymer as materials for new paper diapers in order to introduce closed-loop recycling options [31].

According to these studies, there are potentialities for transforming disposable UBD waste stream into value-added products. However, a number of factors influence the recycling viability, including cost-effective sorting and separation, public perceptions, and sustainable recycle market outlets [32]. A recent review reported that recycling, biodegradation, and pyrolysis are promising, providing a future research direction to enhance the efficiency of these processes in UBD recycling [33]. Nevertheless, it can be underlined that UBD vermicomposting has been cited only once, and it has not been reported within scientific studies or published within the scientific literature. In addition, no details have been provided regarding developing countries and rural areas: scientific literature lacks contribution to this topic.

The hypothesis behind this research was that the use of Californian red earthworms and the mix with cow dung can be employed for treating the biodegradable fraction of disposable UBDs. 
Other studies were carried out with the same methodology for the treatment of kitchen waste [34] and non-recyclable paper waste [35]. However, in the scientific literature, there are no similar studies implemented for the treatment of UBDs with the method already mentioned. Therefore, this paper provided the first results in this framework, underlining the importance of its application in low-to-middle-income areas. It represents progress in the scientific literature, providing new knowledge and new approaches that can support the application of sustainable options toward the circular economy.

For these reasons, the possible application for disposable used diapers composting introduced in this research involved the use of Californian red earthworms with the aim to improve the biodegradability of the waste flow mentioned (i.e., UBDs and cow dung). Other studies suggested that earthworms (Eisenia fetida) can rapidly convert organic fractions into compost, reducing the pathogens to safe levels, and also ingest the heavy metals by mixing waste with other components (i.e., cow dung) [36,37]. Eisenia fetida is available in Bolivian local markets, and it has been used by other authors in order to achieve better performances if compared with other earthworm breeds [38,39]. Therefore, in the current study, the treatment of disposable diapers was implemented, evaluating the degradation of the biomass as a function of the co-composting of cow dung, the adjunct of earthworms, and the addition of activated bacteria $(\mathrm{AB})$. The use of $\mathrm{AB}$ was evaluated since it has been demonstrated that they facilitate the proliferation of indigenous microorganisms, thus accelerating the composting process [40]. The aim was to evaluate the efficiency of the composting process in the best available conditions. Experimental trials were conducted for demonstrating that vermicomposting of disposable UBDs can be a viable recycling option after selective collection and manual pre-treatment in developing regions.

This research follows a previous study conducted in the same Bolivian rural area for treating animal manure with Californian red earthworms. The objective of the previous research was the evaluation of the availability of the treatment components within the context, the viability of its use, and the reliability of the process [41]. Therefore, the research presented in this paper represents the second step toward the application of the vermicomposting process for the treatment of waste organic fractions. The results of UBD composting assessment can be of interest to local and international experts for finding a solution for the final disposal of used diapers and to international scholars involved in improving SWM in low-middle income countries.

\section{Materials and Methods}

\subsection{Study Area}

The research was carried out in the community of Carmen Pampa, Municipality of Coroico (Nor Yungas Province, Department of La Paz, Bolivia). The study area is located at an altitude of $1850 \mathrm{~m}$ a.s.l. at $16^{\circ} 15^{\prime} 31^{\prime \prime}$ South latitude and $67^{\circ} 41^{\prime} 35^{\prime \prime}$ West longitude (Figure 1). This area has precipitation above $2000 \mathrm{~mm}$ per year, reporting an average relative humidity of about $71 \%$. The annual temperature ranges between 17 and $24^{\circ} \mathrm{C}$, with an average temperature of $18.2{ }^{\circ} \mathrm{C}$.

Currently, the city of Coroico has no MSW management plan. Therefore, information about the amount of MSW generated was not available. MSW is simply collected and disposed of in open dumps. According to the 2012 census, about 1813 children with less than 4 years of age live in the city, with a formal population of about 19,397 inhabitants. It has been estimated that each child from 0 to 30 months, on average, uses 5 diapers in $24 \mathrm{~h}$. It can be estimated that about $50 \%$ of the children reported to be from 0 to 4 years old are less than 30 months old. Therefore, about 4533 used diapers can be potentially generated per day. Considering that each UBD weights about $500 \mathrm{~g}$, it can be estimated that the city of Coroico potentially produces about 2.3 tons of disposable UBDs per day, equal to about 827 tons per year. These waste amounts are dumped in the environment. 

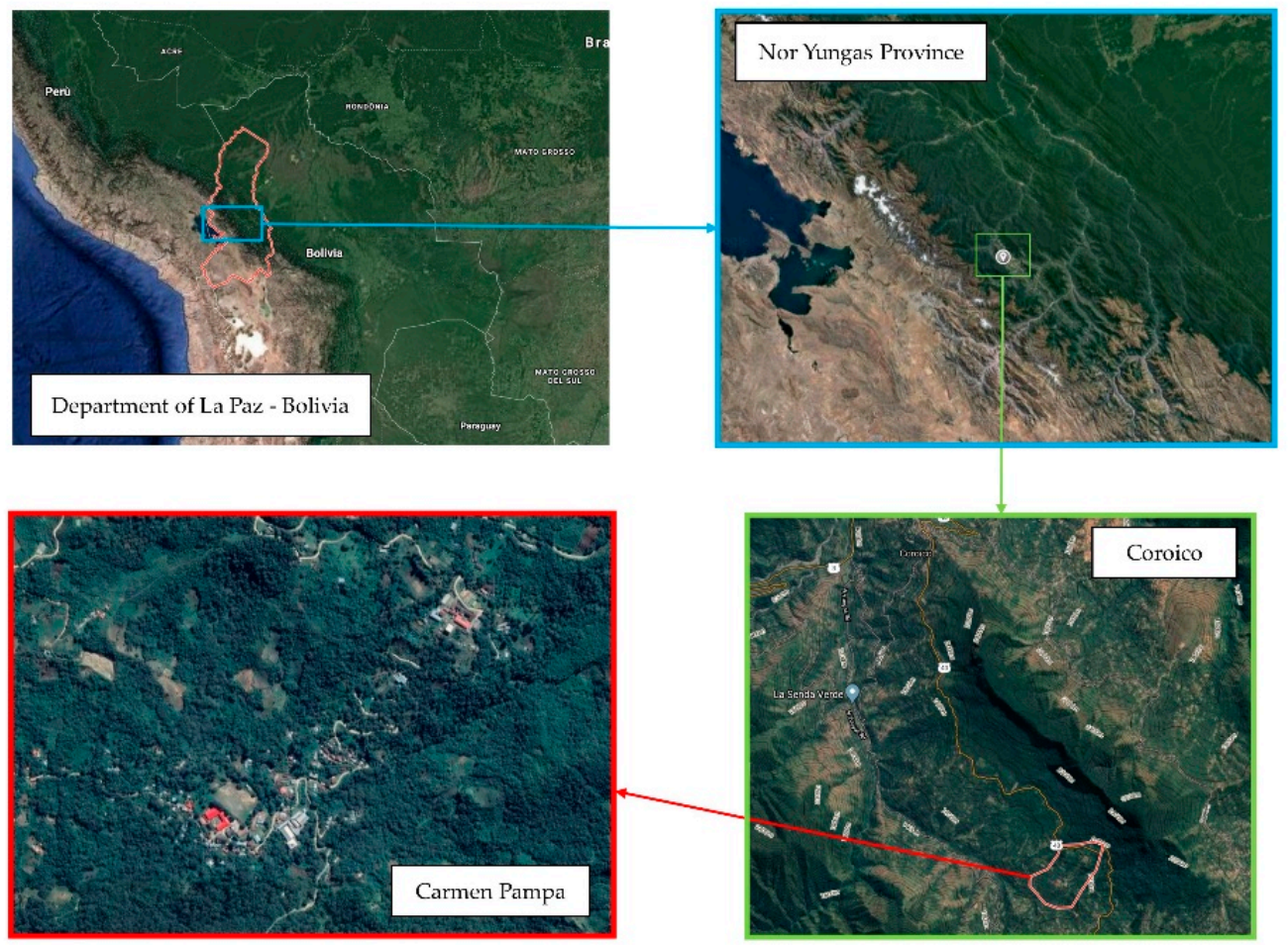

Figure 1. Location of the study area.

\subsection{Experimental Trials}

The aim of the research was to provide a possible solution to the open-dumping of UBDs. To assess the feasibility of the composting process, the research was divided into 5 experimental trials according to the combinations of $\mathrm{AB}$, cow dung, and Californian red earthworms. The list of the combinations used for the investigation, conducted fourfold, are reported in Table 1.

Table 1. Combination of the treatment trials resulting from the combination of activated bacteria (AB), application of cow manure, and earthworms.

\begin{tabular}{lccc}
\hline Treatment & AB & Cow Dung & Earthworms \\
\hline $\mathrm{T}_{1}$ & + & - & + \\
$\mathrm{T}_{2}$ & + & + & - \\
$\mathrm{T}_{3}$ & + & + & + \\
$\mathrm{T}_{4}$ & - & - & + \\
$\mathrm{T}_{5}$ & - & + & + \\
\hline
\end{tabular}

Note: (+) implemented, (-) not implemented.

The experimental units are identified by the letter $\mathrm{T}_{i}$, where $i$ represents the identification number. The third treatment $\left(T_{3}\right)$ refers to the treatment with all the components, while $T_{2}$ is the only trial without the application of earthworms. Overall, the analysis was conducted in 5 months, considering the collection of the diapers, its preparation, treatment, and the final assessment of the products.

The UBDs were collected from the center of Coroico and Carmen Pampa. About 20 families were involved. In total, 500 diapers were collected in one week (about 5 diapers per family per day), from Monday to Friday. This amount was used for all experimental trials, which was equivalent to approximately $250 \mathrm{~kg}$ of the sample ( $0.5 \mathrm{~kg}$ per UBD). 


\subsection{Preparation of the Sample}

\subsubsection{Diaper Selection}

The scheme of the analysis conducted is represented in Figure 2. The samples were prepared starting with the UBDs. After collection, the diapers were opened, and the plastic part was separated from the organic fraction (fecal residues and cellulosic polymers). The organic fraction will be here defined as "substrate." During the preparation of the UBDs, safety precautions and biosecurity measures were adopted in order to reduce the risk exposure of the volunteers who supported the research. Rubber gloves, masks, caps, and chinstraps were used to protect the hands, head, mouth, and nose. While the plastic waste was removed from the diapers, the organic fractions were collected and segregated in specific containers. The plastic bands were mixed with sand and placed in PET bottles to obtain bricks used for the stabilization of the slopes of the garden outside the research area. It represents the only way available locally for plastic recycling, although other solutions should be found in the future. The time required for the separation of the substrate and the plastic materials takes approximately 1 to $2 \mathrm{~min}$ for each UBD.

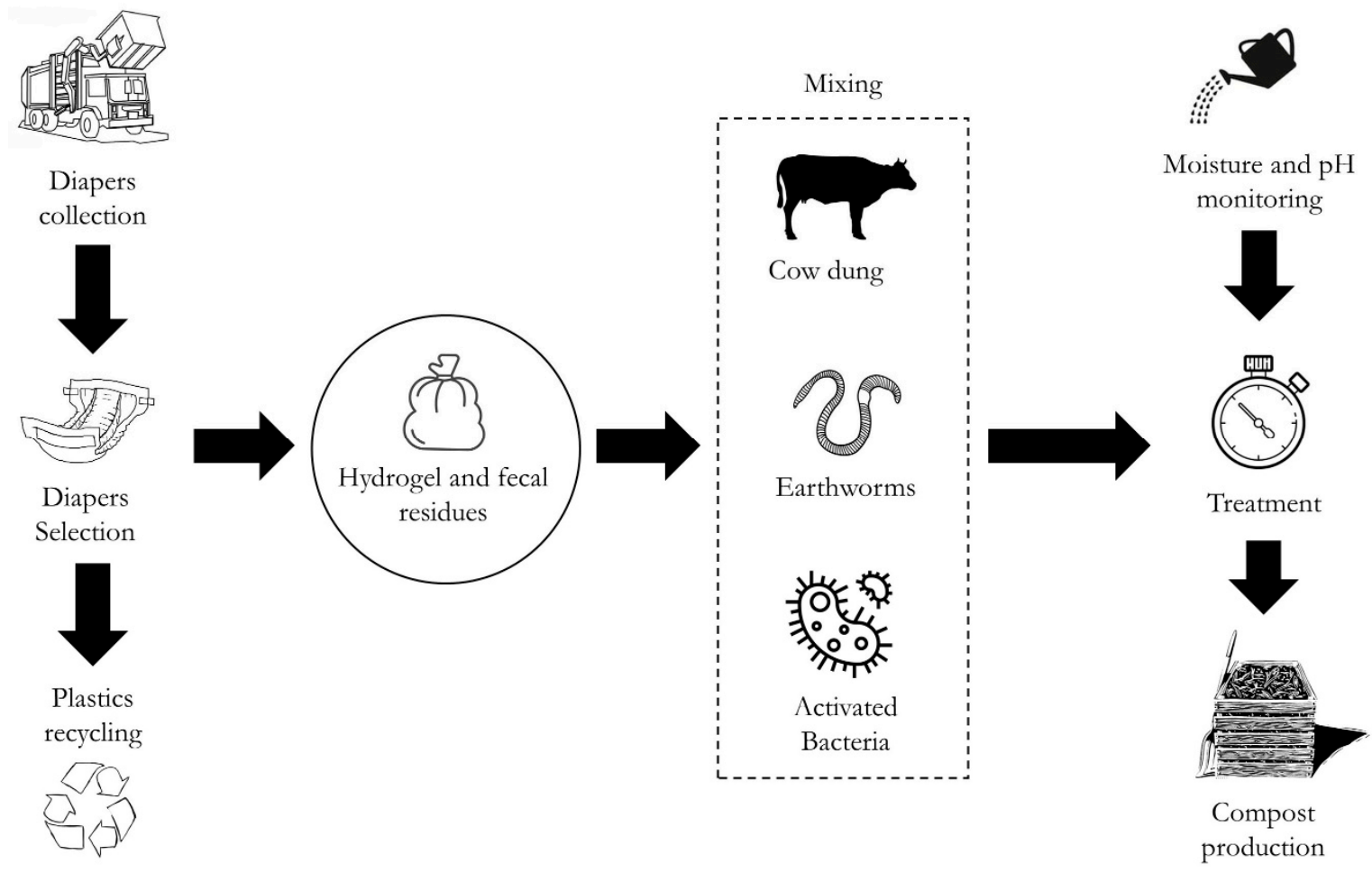

Figure 2. Schematic representation of the analysis and experimental trials.

\subsubsection{Mixing and Preparation of the Trials}

For the preparation of the trials, each sample was mixed according to the combination reported in Table 1. For $\mathrm{T}_{2}, \mathrm{~T}_{3}$, and $\mathrm{T}_{5}, 50 \mathrm{wt} \%$ of the substrate was mixed with the same quantity of cow manure (about $15 \mathrm{~kg}$ ). Therefore, the amounts of UBDs and cow dung corresponded to the proportion of 1:1. At the same time, for $\mathrm{T}_{1}$ and $\mathrm{T}_{4}$, only about $30 \mathrm{~kg}$ of the substrate was used, representing $100 \%$ of the sample. Then, the $A B$ were added to the respective trials $\left(T_{1}, T_{2}\right.$, and $\left.T_{3}\right)$.

The cow dung was collected from local farms, provided by farmers of the near community of Carmen Pampa. The cow dung was used for the trials after 30 days from its generation. Similarly, before treatment, the substrate was left for 5 days in open-air conditions, protected by the light and the environmental agents. During this time period, the samples were prepared, and the treatment time required for the trials was reduced, while the experimental condition was maintained in order to 
assess the statistical significance of the variables considered. In addition, the precomposting period of one week has been suggested by other authors to be ideal for an effective vermicomposting [42].

The $A B$ were made up of phototrophic bacteria, yeast, lactic acid-producing bacteria, and fermentation fungi. These were purchased in the local market. To activate the microorganisms, $2.5 \mathrm{~L}$ of molasses were added to $2.5 \mathrm{~L}$ of $\mathrm{AB}$. The container was hermetically sealed for a period of 15 days. After activation, the $A B$ were mixed with the samples. $T_{1}, T_{2}$, and $T_{3}$ incorporated globally $5 \mathrm{~L}$ of the prepared solution of the $\mathrm{AB}$, while the $\mathrm{T}_{4}$ and $\mathrm{T}_{5}$ were mixed with tap water $(5 \mathrm{~L})$. About $1 \mathrm{~L}$ of solution or tap water was added to every $5-6 \mathrm{~kg}$ of the sample.

\subsubsection{Location of the Samples}

After mixing, the samples were all located in 20 wooden boxes built specifically for the research. The wooden boxes had dimensions of $30 \times 20 \times 15 \mathrm{~cm}$ (length $\times$ width $\times$ depth). About $2.5 \mathrm{~kg}$ of the sample was added to each wooden box. The boxes were located in a covered and controlled environment, maintaining a constant $80 \%$-moisture content, and guaranteeing an average temperature above $21^{\circ} \mathrm{C}$. The environmental temperature was measured every morning and night, while the moisture content was measured by a hygrometer. Irrigation was carried out daily by means of a manual watering can. Approximately $0.2 \mathrm{~L}$ per experimental unit was added, which was equal to $80 \mathrm{~mL}$ of water per $\mathrm{kg}$ of biomass per day.

Finally, in $\mathrm{T}_{1}, \mathrm{~T}_{3}, \mathrm{~T}_{4}$, and $\mathrm{T}_{5}, 50$ Californian red earthworms were placed per box. Afterward, the boxes were covered with cardboard to maintain humidity, reduce light, and avoid an attack from external vectors. Therefore, about 20 earthworms were added per $\mathrm{kg}$ of biomass. Figure 3 reports the photos related to the steps of the preparation of the experimental trials. The trials were evaluated for a maximum period of 5 weeks, depending on the time required for the process. For every sample, the treatment ended when a final odorless, black, and homogenous matter was obtained.

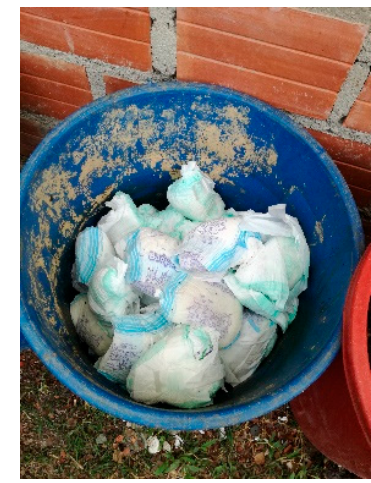

(a)

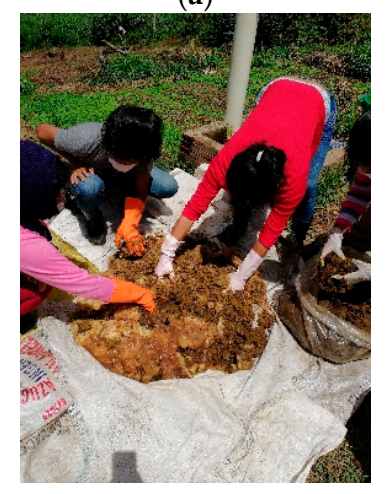

(c)

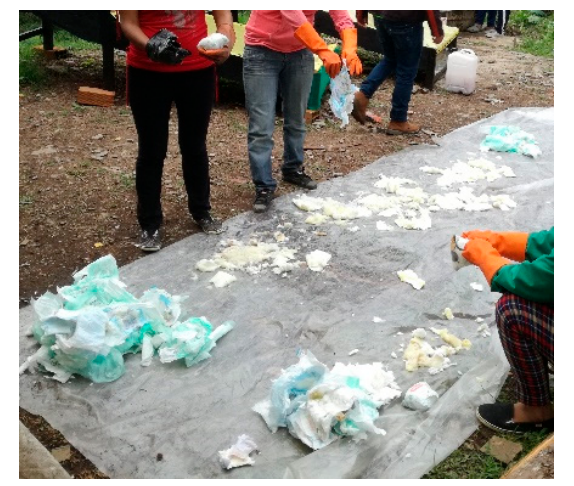

(b)

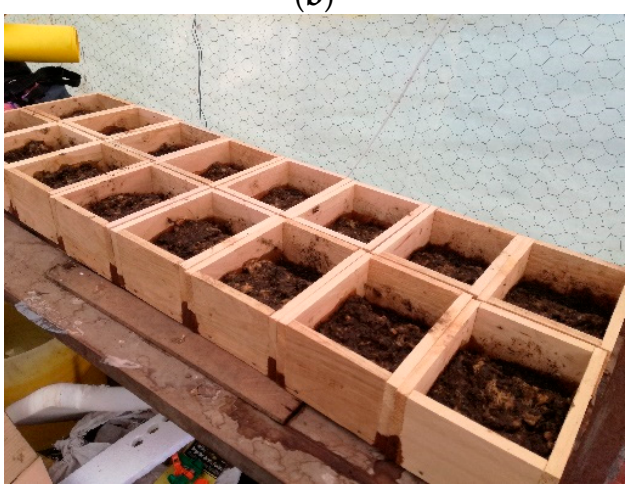

(d)

Figure 3. Photos of the experimental procedure: (a) collection of the used baby diapers (UBDs); (b) preparation of the substrate for the treatment; (c) mixing with cow dung, earthworms, and AB; (d) location in wooden boxes. 


\subsection{Variables Considered}

Four parameters were evaluated to compare the processes:

- $\quad$ Acidity $(\mathrm{pH})$;

- Decomposition time;

- Earthworm growth;

- Compost production (in mass).

The acidity was measured with a $\mathrm{pH}$-meter before and after the treatment. The initial and final $\mathrm{pH}$ were recorded, and the variation was calculated. The acidity was measured for three different parts of the sample. The average was registered and considered as the $\mathrm{pH}$ of reference of the entire replicate of the experimental trial.

The time required to decompose each experimental unit was chosen in terms of the treatment time (days, $24 \mathrm{~h}$ ) required for generating compost. The compost produced should be homogeneous in size, odor, and form. Therefore, the changes were evaluated by visualization. For evaluating the earthworm reproduction, the number of earthworms before and after the treatment was counted for the sample that contained earthworms and that managed to produce compost. The number of reproduced earthworms was calculated considering the total sum of the young earthworms $(2-3 \mathrm{~cm}$ long) and adults (7-10 cm in length). The amount of compost produced was weighed at the end of the process. The variation between the starting point and the endpoint was measured for counting the mass loss after treatment.

Finally, a chemical analysis of the compost produced was implemented to compare it with other biological and chemical fertilizers. In particular, the analysis was conducted by an external consultant at the Bolivian Institute of Science and Technology, who is specialized in chemical analysis. Nitrogen, phosphorous, potassium, calcium, and magnesium compounds were evaluated in terms of percentage in weight. The results were compared with other data available in the literature related to chemical concentrations.

\subsection{Statistical Analysis}

The results are presented in terms of average plus the standard deviation. The analysis of variance (ANOVA) method was used for assessing the statistical significance of the mass loss, earthworms' growth rate, $\mathrm{pH}$, and treatment time among the trials and pre- and post-treatment conditions. The significance level was considered acceptable for an error equal to $5 \%(p$-value $<0.05)$.

\section{Results}

\subsection{Effective Decomposition of the Substrate}

Unlike the other treatments, $\mathrm{T}_{1}$ and $\mathrm{T}_{4}$ did not manage to decompose the substrate. The substrate, after 15 days of treatment, was submerged by algae and fungi, without any indication of biomass decomposition (Figure 4). Two factors may affect the treatment: the lack of a homogeneous substrate and the acidity of the substrate that can affect the bacteria's growth and the life of the earthworms [43]. The research demonstrated that, without cow dung, aerobic degradation was not well implemented. The cow dung contributed to the biological activity due to the bacterial action just present in the excrement. In this case, cow dung could be compared as an inoculum for improving mineralization conditions [44]. Therefore, $\mathrm{T}_{1}$ and $\mathrm{T}_{4}$ did not manage to produce compost, and the treatment had to stop. These hypotheses were confirmed by the $\mathrm{pH}$ analysis, while this evidence demonstrated the importance of the co-composting of the UBD organic fraction. 


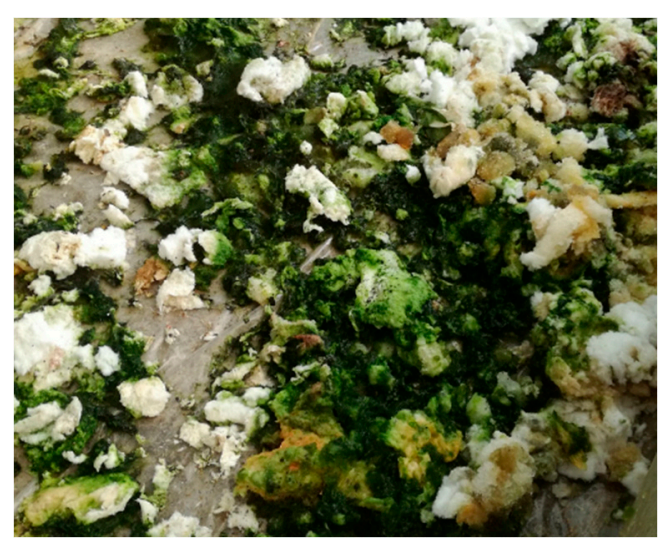

Figure 4. Experimental trials $\left(\mathrm{T}_{1}\right.$ and $\mathrm{T}_{4}$-without cow dung) covered by mildew after 15 days of treatment.

\section{2. $\mathrm{pH}$ Analysis}

According to the ANOVA, the initial $\mathrm{pH}$ variables presented significant differences $\left(\mathrm{F}_{[4,19]}=24.59\right.$, $p<0.05)$ within treatments. In particular, the sample was more acidic when cow dung and AB were not mixed in the biomass. The results are presented in Figure 5. It can be viewed that without cow dung and $\mathrm{AB}$, the average acidity of the sample did not overcome the $4.4 \pm 0.2 \mathrm{pH}$. It means that cow dung and $\mathrm{AB}$ make the environment more adapt to earthworms' growth and the composting process. Acid environments inhibit the activity of aerobic bacteria [45]. These results provided more insight into the death of the earthworms and the formation of mildew in the case of absence of cow dung in $T_{1}$ and $T_{4}$ as presented in the previous subsection. At the same time, the trials showed significant differences between the initial and final $\mathrm{pH}\left(\mathrm{F}_{[4,19]}=16.76, p<0.05\right)$, while there were no significant differences within the final $\mathrm{pH}$ measurement $\left(\mathrm{F}_{[1,9]}=0.78, p=0.6\right)$. These results provided indications about the increase of the $\mathrm{pH}$ both in the biomass stabilized and the trials that did not allow to obtain compost.

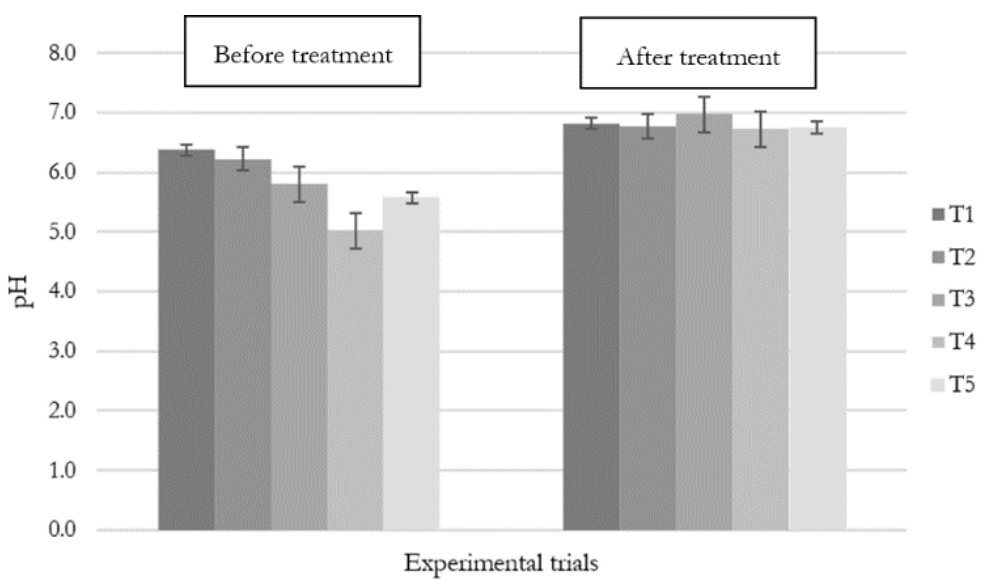

Figure 5. Average $\mathrm{pH}$ of the experimental trials before and after treatment.

\subsection{Treatment Time}

Regarding the treatment time, according to the ANOVA, there were significant differences among the trials $\left(\mathrm{F}_{[4,19]}=12.08 ; p<0.05\right)$. In $\mathrm{T}_{3}$ (with $\mathrm{AB}$, cow dung, and earthworms) and $\mathrm{T}_{5}$ (without $\mathrm{AB}$, but with cow dung and earthworms), the time required for obtaining compost was estimated to be between $27.8 \pm 0.5$ and $32.3 \pm 0.9$ days, respectively, while $\mathrm{T}_{2}$ did not achieve decomposition within the five weeks of treatment (the time boundary of the analysis). In total, about 55-60 days are globally required for the biomass decomposition of cow dung and earthworms, while more than 70 days are required for the treatment of the substrate mixed only with manure. The photos of the compost 
produced are reported in Figure 6. These results are relevant for demonstrating the importance of the presence of both earthworms and cow dung to obtain compost from UBDs, optimizing the treatment time and environmental conditions. As visible in Figure 6, cow dung and the UBDs' organic fraction were not recognizable, demonstrating the effectiveness of the composting process.

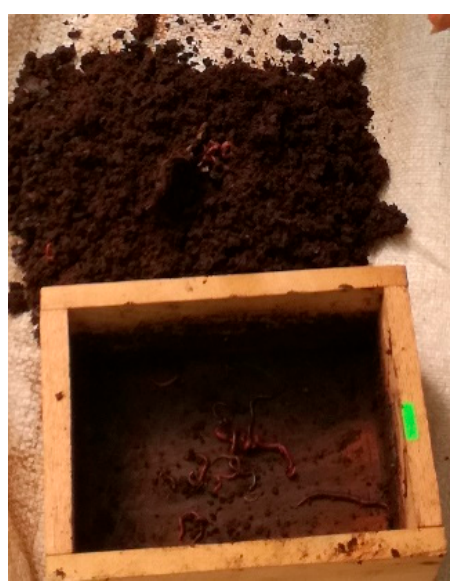

(a)

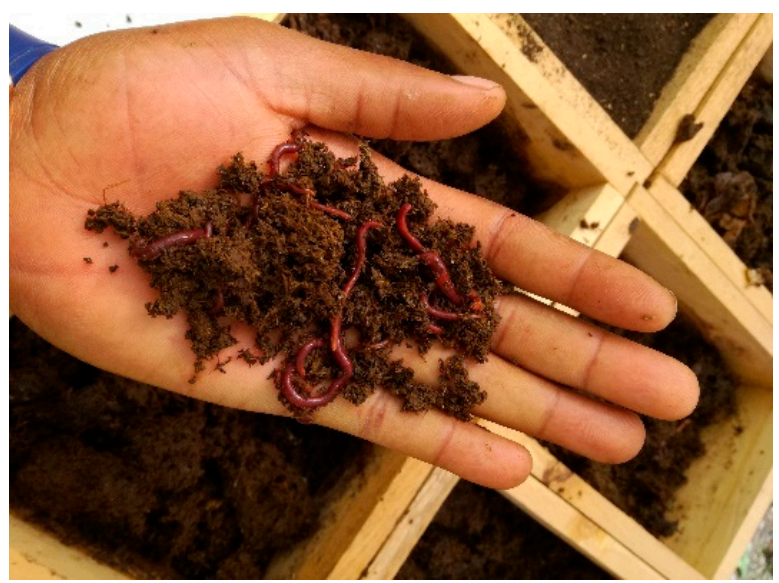

(b)

Figure 6. Photos of the products: (a) Compost produced after treatment $\left(\mathrm{T}_{3}\right.$ and $\left.\mathrm{T}_{5}\right)$, and (b) Californian red earthworms.

\subsection{Earthworms Growth Rate}

According to the significance in terms of $\mathrm{pH}$ and treatment time, the production of earthworms was also significantly different among the trials $\left(\mathrm{F}_{[4,19]}=16.76 ; p<0.05\right)$. In particular, $\mathrm{T}_{5}$ and $\mathrm{T}_{3}$, the ones that allowed obtaining good results in terms of compost production, showed an average increase in the number of earthworms of about $56.5 \pm 7.0$ and $129.5 \pm 62$, respectively. It means that the implementation of the composting process with the aid of earthworms was also viable in terms of the Eisenia fetida growth. Acidity, microorganism activity, and texture of the samples were therefore appropriated. In these trials, $T_{3}$ and $T_{5}$ produced an amount of compost equal to $2.23 \pm 0.4 \mathrm{~kg}$ and $2.35 \pm 0.2 \mathrm{~kg}$, respectively, with the humidity maintained at $80-90 \%$. Therefore, the mass balance provided positive indications in terms of biomass degradation. The outcomes of these trials provided useful information for considering the use of $\mathrm{AB}$ significantly for the improvement of the earthworms' growth rate. However, the treatment time decreased by only five days, suggesting the use of $\mathrm{AB}$ for increasing earthworms' growth rate but not for improving the composting process: five days cannot be considered as an effective improvement for justifying another expense in a developing rural area.

\subsection{Chemical Composition}

Finally, positive results were also obtained for the chemical composition of the compost. Figure 7 reports the results of the chemical analysis. The concentrations obtained can be compared with other types of compost as well as with other biomasses described in further scientific papers: composts with over $1 \%$ nitrogen can be used as a fertilizer [46]. These results are encouraging for considering UBD composting with Californian red earthworms and cow dung as a promising option for its treatment. At the same time, the use of $\mathrm{AB}$ can be considered not necessary since the time saved and the earthworms production is relatively improved, while the main focus of rural areas in low-income regions is to simplify the system and save financial resources. On the other hand, the research provided interesting results for starting the production of compost from disposable UBDs, which can be obtained by mixing Californian red earthworms and cow dung. 


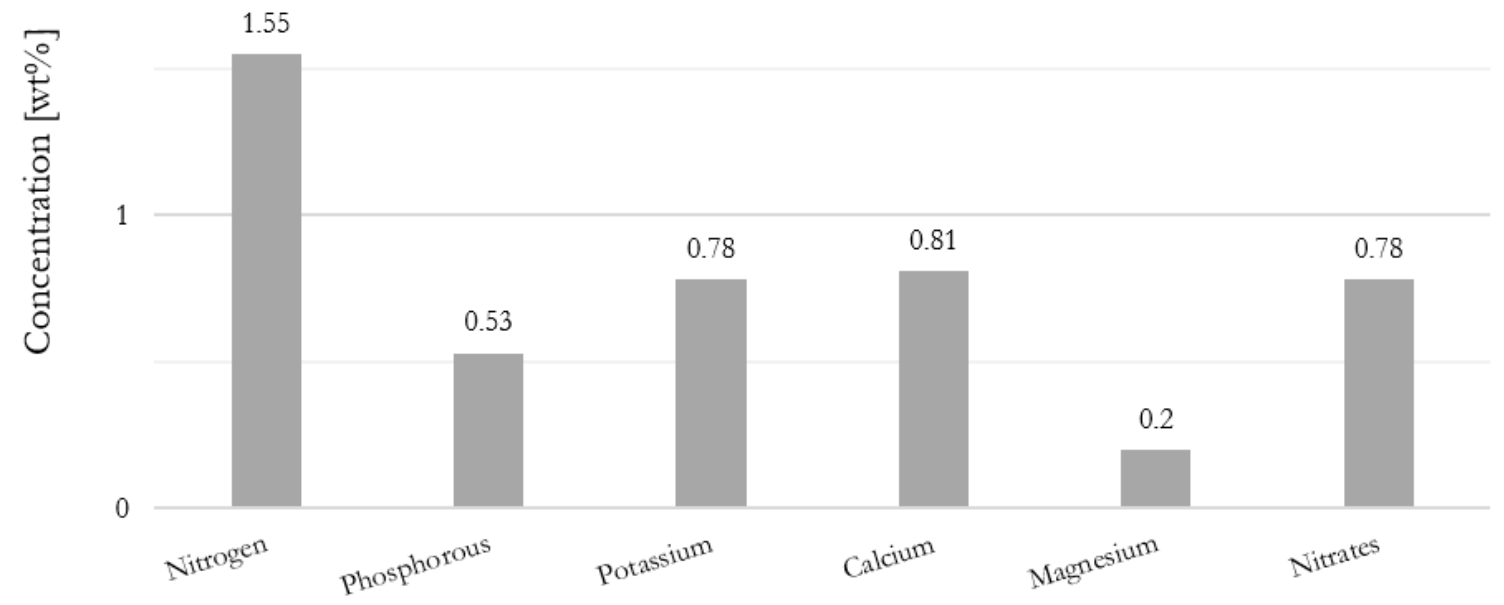

\section{Chemical compounds}

Figure 7. Chemical composition (in percentage by weight) of the compost produced after treatment $\left(\mathrm{T}_{3}\right)$.

\section{Discussion}

\subsection{Lessons Learned and Potential Applications}

The research allows providing useful preliminary insights about the treatment of UBDs in areas where waste open dumping is a big issue. The article provides three main indications:

- The biological part of UBDs can be treated by a co-composting and vermicomposting process, providing interesting results for its implementation in areas with low financial sustainability and a lack of SWM systems;

- The $\mathrm{pH}$ of the biomass increases with the addition of cow dung and $\mathrm{AB}$, improving the biological decomposition of baby diapers;

- Composting of used diapers cannot be implemented without the mix of cow dung.

These results are relevant in order to introduce reliable treatment options in areas with scarce resources. It is imperative to underline the importance of good management of UBDs' plastic and organic materials, mostly in developing countries [32]. The outcomes of the research demonstrated that the addition of cow dung is necessary, which is a source of substrate for earthworms, improving the environmental condition of the samples. Co-composting with cow dung is usually also implemented for other organic fractions [47]. $T_{1}$ and $T_{4}$ are good examples for understanding the negative impacts related to the lack of cow dung for treating UBDs.

Therefore, the preliminary results can be employed to consider that the whole process has some issues that should be solved in order to be scaled up. At the same time, it suggests investigating present and future opportunities in UBD recycling. The challenges and the positive prospects are schematically reported in Table 2 . The benefits of the treatment option presented here are twofold: The treatment of UBDs, avoiding mixed waste in open dumps; the treatment of cow dung as second waste flow reduced, producing compost that can be used for agricultural purposes. These achievements allow transforming waste into resources, supporting the principles of the circular economy. 
Table 2. Pros and cons of the treatment system according to the steps required for its implementation.

\begin{tabular}{|c|c|c|c|}
\hline $\begin{array}{l}\text { Treatment } \\
\text { Requirements }\end{array}$ & Opportunities & Weaknesses & Possible Solutions \\
\hline $\begin{array}{l}\text { UBD selective selection } \\
\text { at the source }\end{array}$ & $\begin{array}{l}\text { The selective collection provides positive } \\
\text { effects in terms of the separation of the } \\
\text { waste flow, making it recyclable. At the } \\
\text { same time, this practice involves the } \\
\text { citizens, improving their awareness of } \\
\text { environmental terms. }\end{array}$ & $\begin{array}{l}\text { The involvement of the population } \\
\text { is not easy to achieve. The public } \\
\text { acceptance of the treatment option } \\
\text { introduced can be a barrier that } \\
\text { should be overcome. }\end{array}$ & $\begin{array}{l}\text { Public campaigns, incentives, seminars, and } \\
\text { involvement of primary schools allow } \\
\text { supporting public acceptance. }\end{array}$ \\
\hline $\begin{array}{l}\text { Separation of the organic } \\
\text { fraction from the plastic } \\
\text { residues and mixing of } \\
\text { the components }\end{array}$ & $\begin{array}{l}\text { The selection of recyclable plastic and } \\
\text { compostable hydrogel from the UBDs is } \\
\text { the way forward for a circular economy of } \\
\text { the disposable UBDs in developing } \\
\text { countries. It represents the only way of } \\
\text { implementing the co-composting process. }\end{array}$ & $\begin{array}{l}\text { The manual selection poses a } \\
\text { health and biological risk to the } \\
\text { operators. Vectors, such as } \\
\text { mosquitos or flies, can transport } \\
\text { pathogens, mainly if the manual } \\
\text { selection is not implemented in } \\
\text { closed environments. }\end{array}$ & $\begin{array}{l}\text { Innovative and mechanic treatment options } \\
\text { should be introduced in order to reduce the } \\
\text { possible contact of the waste with the } \\
\text { operators. Personal protective equipment } \\
\text { and safety precautions should be used as } \\
\text { well as specific environment and containers } \\
\text { must be employed. }\end{array}$ \\
\hline Use of $A B$ & $\begin{array}{l}\text { The application of } \mathrm{AB} \text { to the substrate } \\
\text { allows increasing the } \mathrm{pH} \text { of the biomass } \\
\text { and improving the characteristics of the } \\
\text { earthworms' growing environment. }\end{array}$ & $\begin{array}{l}\text { The implementation of the } \mathrm{AB} \\
\text { requires investment in its } \\
\text { acquisition, reducing the financial } \\
\text { sustainability of the process. }\end{array}$ & $\begin{array}{l}\mathrm{AB} \text { are not required to be implemented for } \\
\text { optimizing the co-composting process. Its } \\
\text { application depends on local needs and } \\
\text { financial sustainability. }\end{array}$ \\
\hline $\begin{array}{l}\text { Use of Californian red } \\
\text { earthworms }\end{array}$ & $\begin{array}{l}\text { The use of Californian red earthworms is } \\
\text { required in order to improve the process } \\
\text { and reduce the treatment time needed for } \\
\text { converting the UBD into compost. Their } \\
\text { application reduces the time necessary for } \\
\text { the composting process. }\end{array}$ & $\begin{array}{l}\text { The Californian red earthworms } \\
\text { cannot be available everywhere in } \\
\text { the world. Moreover, their } \\
\text { application requires a first } \\
\text { investment in terms of } \\
\text { financial resources. }\end{array}$ & $\begin{array}{l}\text { Studies related to the most appropriated } \\
\text { local earthworm for treating organic waste } \\
\text { can be implemented. If appropriated, } \\
\text { breeding of such variety of earthworm } \\
\text { should also be introduced locally. These } \\
\text { activities allow creating new jobs and } \\
\text { appropriate systems for the local } \\
\text { developing contexts. }\end{array}$ \\
\hline Use of cow dung & $\begin{array}{l}\text { The use of manure is imperative in order } \\
\text { to guarantee the earthworms' activity and } \\
\text { the biodegradation. Its application } \\
\text { represents another opportunity to recover } \\
\text { another waste flow. }\end{array}$ & $\begin{array}{l}\text { The manure application requires } \\
\text { its local availability. The } \\
\text { transportation of this waste } \\
\text { fraction might be costly. }\end{array}$ & $\begin{array}{l}\text { The implementation of the manure requires } \\
\text { the presence of farms near the treatment } \\
\text { area. Therefore, UBDs can be transported } \\
\text { farther, in order to guarantee the location of } \\
\text { the treatment close to the farms. }\end{array}$ \\
\hline $\begin{array}{l}\text { Applications of the } \\
\text { compost }\end{array}$ & $\begin{array}{l}\text { The outcome of the treatment process is } \\
\text { compost that can be implemented as a } \\
\text { substitute for chemical fertilizers. Its } \\
\text { application allows cultivating biological } \\
\text { products reducing economic expenses } \\
\text { and pollution of the water bodies. }\end{array}$ & $\begin{array}{l}\text { The main barrier for the use of } \\
\text { compost produced from baby } \\
\text { diapers is the availability of the } \\
\text { market. Local farmers should be } \\
\text { encouraged to use it. }\end{array}$ & $\begin{array}{l}\text { Public and farmer involvement should } \\
\text { support the introduction of the process in } \\
\text { order to show its potentialities. At the same } \\
\text { time, certifications, quality assurance, and } \\
\text { periodic assessments are required for } \\
\text { guaranteeing the reliability of the compost } \\
\text { as a fertilizer. }\end{array}$ \\
\hline
\end{tabular}

\subsection{Limitation of the Analysis and Future Developments}

The experimental trials were implemented in a Bolivian rural area where a lack of economic sustainability and technologies make it difficult to implement full-scale research and assessment. The survey presented in this paper provided preliminary results of a topic still poorly explored in the scientific literature. Future evaluations that should be conducted by both scholars and international stakeholders is the cost analysis in parallel with an environmental assessment of the approach presented in this paper, as recommended by other authors [48]. The scientific literature suggests quantifying the environmental impacts reduced thanks to waste-treatment systems as well as introducing financial sustainability assessments. For example, both environmental and costs analysis were implemented for evaluating the impacts due to pollution from waste landfill and incineration [49] or for comparing the options available for waste disposal [50].

It is important to demonstrate the potentiality and the replicability of the treatment option suggested in this research in other rural areas that present similar conditions in terms of environmental and economic sustainability. Other three analyses should be carried out in future studies:

- The percentage of cow dung that can be mixed with diaper hydrogel in order to obtain compost;

- Analysis of possible low-tech mechanization systems in order to separate baby diaper hydrogel for optimizing the process and reducing biological and occupational risks;

- To measure the heavy metal contents and the level of degradation of pathogens in order to provide more details about infection issues.

While the first point can be implemented locally with low technical and management requirements, representing a future development of the current research, the second and third points are barriers that cannot be overcome in Carmen Pampa due to the lack of resources. Therefore, the researchers who conducted this analysis invite international scholars to work on and explore these issues in future 
surveys in order to provide complete insights to international engineers into implementing disposable UBD treatment solutions also in developing countries' rural areas.

The results obtained by the research can support the introduction of new recycling systems in developing rural areas, which represent a global challenge [51,52]. These findings suggest a possible application of the co-composting process for treating UBDs in developing countries, considerably reducing the waste flow disposed of in open-dumping areas. The possible mechanism behind this trend consists of the replicability of the process in other countries with low financial and technical sustainability, as well as the easy application of the process that can be scaled up for small towns or rural areas. These conditions are imperative for developing countries [53]. It can also be appropriated for the neighborhoods of developing cities, although different dynamics should be considered [54].

\subsection{Remarks and Policy Implications}

For improving UBD treatment and recycling, an automized and mechanical selection is necessary. As suggested by other authors, this process involves screening and enzymatic treatment for the plastic fraction, and screening, cleaning, and thickening of the fiber fraction [55]. These systems are costly and developing countries might not be ready to implement them due to the lack of selective collection procedures and financial resources. The careful waste selection at the source should be implemented for reducing the life-cycle impacts while ensuring that human health and environmental risks are controlled. Therefore, special forms of treatment at the end of the life stage could require significant structural changes in the waste management system [56].

These assumptions are challenging in low-income countries. In parallel with the lack of technology, economic feasibility should be considered. In particular, the collection and transportation of the diapers' waste, which accounts for much of the cost, need to be optimized. Engagement programs contribute to promoting the service to the public. However, the main issues regard the time for the citizens to reach a full understanding of how to use the selective collection service, the lack of efficiency in the collection and transportation system, and the limited number of participants [57].

In Bolivia, waste-prevention initiatives are still in their early stages, and there are regulatory, social, and political obstacles to enacting waste-prevention policies. However, policy approaches should be multi-faceted and address citizens' attitudes and waste logistical aspects, addressing the identifications of concerns regarding UBD wastage [58]. Incentives can be provided to businesses and households to use reusable baby diapers or to deliver the UBDs to specific bags or waste containers. At the same time, high-value policy approaches can support research and development focused on improved UBD treatment options. Finally, waste selective collection and recycling policies can substantially reduce the amount of waste disposed of.

Alternative solutions should be implemented, such as the use of cloth diapers and glueless diapers. Cloth diapers show better environmental performance than disposable diapers, mainly due to their end-of-life treatment in sanitary landfills. Domestic laundering of diapers is a good alternative regarding its environmental performance, because of its low energy consumption. However, consumers might be unwilling to accept this additional labor [59]. Alternatively, glueless diapers reduce the consumption of raw materials by $9.2 \mathrm{~g}$ per diaper, primary energy demand by $752 \mathrm{~kJ}$ per diaper, and global warming potential by $10.4 \mathrm{~g} \mathrm{CO}_{2}$-eq. per diaper, reducing the costs by $11 \%$ compared to the conventional product [60]. However, eco-design will not help to resolve the waste generation associated with the use of disposable baby diapers [61]. Therefore, the issue will remain, and developing countries require urgent solutions for treating these types of residues. The current research suggested that co-composting treatment by Californian red earthworms and cow dung can be an appropriate option.

\section{Conclusions}

The research presented in this paper provides the first attempt to find a solution for implementing UBD recycling in developing countries. Though some limitations are detectable due to the scarce resource availability in the area, preliminary results were obtained in order to provide some 
understanding of the application of the vermicomposting treatment for reducing environmental impact and providing solutions to MSW open dumping.

The research demonstrated that vermicomposting can be implemented for treating disposable UBDs mixed with cow dung within 60 days of treatment time. The major outcome of the research is that the substrate without cow dung did not manage to decompose the substrate since, after 15 days of treatment, it was submerged by algae and fungi. Cow dung combined with Californian red earthworms allowed obtaining good results in terms of compost production, showing an average increase in the number of earthworms of about $56.5 \pm 7.0$ without AB. The composting treatment time was $32.3 \pm 0.9$ days with cow dung and Californian red earthworms, with about 55-60 days globally required for biomass decomposition in the environmental conditions described.

These findings can have potential application for developing regions with poor technical and financial resources in order to reduce the open dumping of UBDs. The treatment of disposable UBDs required selective collection systems in place, pre-treatment solutions, and treatment options viable for developing regions. These requirements are challenging in rural areas. The current research demonstrated that the biodegradable fraction of waste UBDs can be recovered producing compost with chemical characteristics optimal for its application as a natural fertilizer. Future perspectives are related to more investigations for the application of sustainable mechanical pre-selection, environmental assessment, and costs analysis in order to provide more details on the potentialities of the UBD co-composting process. Although future investigations are still required, this paper represents the first attempt to provide data related to this technique within the scientific literature.

At a global level, SWM is challenging. Appropriate technologies and approaches are required in developing countries since the growth rate of the population and the lack of economic resources represent a reason for concern. The research conducted in Carmen Pampa is an example of the requirement to also investigate possible innovative recycling solutions in poor areas with the support of international alliances and the application of appropriate technologies. In conclusion, the results presented in this paper allow supporting the achievement of the targets provided by the SDGs and introduced by the United Nations. The study can be considered a novel contribution to boosting the circular economy and the global call for action toward sustainable development.

Author Contributions: Conceptualization, M.L.N.P. and N.F.; methodology, M.L.N.P. and N.F.; validation, N.F.; formal analysis, M.L.N.P.; investigation, M.L.N.P.; data curation, M.L.N.P. and N.F.; writing-original draft preparation, N.F.; writing-review and editing, N.F.; supervision, V.T. All authors have read and agreed to the published version of the manuscript.

Funding: This research received no external funding.

Conflicts of Interest: The authors declare no conflict of interest.

\section{References}

1. Ferronato, N.; Torretta, V. Waste mismanagement in developing countries: A review of global issues. Int. J. Environ. Res. Public Health 2019, 16, 1060. [CrossRef] [PubMed]

2. Kulkarni, B.N. Environmental sustainability assessment of land disposal of municipal solid waste generated in Indian cities-A review. Environ. Dev. 2020, 33. [CrossRef]

3. Wilson, D.C.; Velis, C.A. Waste management-Still a global challenge in the 21st century: An evidence-based call for action. Waste Manag. Res. 2015, 1049-1051. [CrossRef] [PubMed]

4. Quicker, P.; Consonni, S.; Grosso, M. The Zero Waste utopia and the role of waste-to-energy. Waste Manag. Res. 2020, 35, 481-484. [CrossRef]

5. Yaman, C. Investigation of greenhouse gas emissions and energy recovery potential from municipal solid waste management practices. Environ. Dev. 2020, 33. [CrossRef]

6. Kaza, S.; Yao, L.; Bhada-Tata, P.; Van Woerden, F. What a Waste 2.0: A Global Snapshot of Solid Waste Management to 2050; The World Bank: Washington, DC, USA, 2018.

7. Rodić, L.; Wilson, D.C. Resolving governance issues to achieve priority sustainable development goals related to SWM in developing countries. Sustainability 2017, 9, 404. [CrossRef] 
8. Hettiarachchi, H.; Meegoda, J.N.; Ryu, S. Organic waste buyback as a viable method to enhance sustainable municipal solid waste management in developing countries. Int. J. Environ. Res. Public Health 2018, 15, 2483. [CrossRef]

9. Ferronato, N.; Gorritty Portillo, M.A.; Guisbert Lizarazu, E.G.; Torretta, V. Application of a life cycle assessment for assessing municipal solid waste management systems in Bolivia in an international cooperative framework. Waste Manag. Res. 2020, 38, 98-116. [CrossRef]

10. Kazuva, E.; Zhang, J. Analyzing municipal solid waste treatment scenarios in rapidly urbanizing cities in developing countries: The case of dar es salaam, Tanzania. Int. J. Environ. Res. Public Health 2019, 16, 2035. [CrossRef]

11. Bovea, M.D.; Powell, J.C. Developments in life cycle assessment applied to evaluate the environmental performance of construction and demolition wastes. Waste Manag. 2016, 50, 151-172. [CrossRef]

12. Cocarta, D.M.; Rada, E.C.; Ragazzi, M.; Badea, A.; Apostol, T. A contribution for a correct vision of health impact from municipal solid waste treatments. Environ. Technol. 2009, 30, 963-968. [CrossRef]

13. Alam, A.; Tabinda, A.B.; Qadir, A.; Butt, T.E.; Siddique, S.; Mahmood, A. Ecological risk assessment of an open dumping site at Mehmood Booti Lahore, Pakistan. Environ. Sci. Pollut. Res. 2017, 24, 889-899. [CrossRef] [PubMed]

14. Fauziah, S.H.; Agamuthu, P. Trends in sustainable landfilling in Malaysia, a developing country. Waste Manag. Res. 2012, 30, 656-663. [CrossRef] [PubMed]

15. Arena, U.; Ardolino, F.; Di Gregorio, F. Technological, environmental and social aspects of a recycling process of post-consumer absorbent hygiene products. J. Clean. Prod. 2016, 127, 289-301. [CrossRef]

16. Colón, J.; Ruggieri, L.; Sánchez, A.; González, A.; Puig, I. Possibilities of composting disposable diapers with municipal solid wastes. Waste Manag. Res. 2011, 29, 249-259. [CrossRef]

17. Torrijos, M.; Sousbie, P.; Rouez, M.; Lemunier, M.; Lessard, Y.; Galtier, L.; Simao, A.; Steyer, J.P. Treatment of the biodegradable fraction of used disposable diapers by co-digestion with waste activated sludge. Waste Manag. 2014, 34, 669-675. [CrossRef]

18. Moqbel, S.; El-tah, Z.; Haddad, A. Anti-littering in developing countries: Motivating the people of Jordan. Waste Manag. Res. 2020. [CrossRef]

19. Brunner, P.H.; Fellner, J. Setting priorities for waste management strategies in developing countries. Waste Manag. Res. 2007, 25, 234-240. [CrossRef]

20. INE Bolivia. Solid Waste Generation in the 9 Capital Cities and El Alto [ $\backslash$ La Generación de Basura de las 9 Ciudades Capitales y El Alto_In Spanish]; Instituto Nacional de Estadística (Bolivia): La Paz, Bolivia, 2017.

21. Solano Meza, J.K.; Rodrigo-Ilarri, J.; Hernández, C.P.R.; Rodrigo-Clavero, M.E. Analytical methodology for the identification of critical zones on the generation of solid waste in large urban areas. Int. J. Environ. Res. Public Health 2020, 17, 1196. [CrossRef]

22. Ragazzi, M.; Catellani, R.; Rada, E.C.; Torretta, V.; Salazar-Valenzuela, X. Management of municipal solid waste in one of the Galapagos islands. Sustainability 2014, 6, 9080-9095. [CrossRef]

23. Valencia-Vázquez, R.; Pérez-López, M.E.; Vicencio-De-La-Rosa, M.G.; Martínez-Prado, M.A.; Rubio-Hernández, R. Knowledge and technology transfer to improve the municipal solid waste management system of Durango City, Mexico. Waste Manag. Res. 2014, 32, 848-856. [CrossRef] [PubMed]

24. Ferronato, N.; Torretta, V.; Ragazzi, M.; Rada, E.C. Waste mismanagement in developing countries: A case study of environmental contamination. UPB Sci. Bull. Ser. D Mech. Eng. 2017, 79, 185-196.

25. Al-Jabari, M.; Ghyadah, R.A.; Alokely, R. Recovery of hydrogel from baby diaper wastes and its application for enhancing soil irrigation management. J. Environ. Manag. 2019, 239, 255-261. [CrossRef] [PubMed]

26. Karimi, H.; Yu, Q.L.; Brouwers, H.J.H. Valorization of waste baby diapers in concrete. Resour. Conserv. Recycl. 2020, 153, 104548. [CrossRef]

27. Colón, J.; Mestre-Montserrat, M.; Puig-Ventosa, I.; Sánchez, A. Performance of compostable baby used diapers in the composting process with the organic fraction of municipal solid waste. Waste Manag. 2013, 33, 1097-1103. [CrossRef]

28. Espinosa-Valdemar, R.M.; Vázquez-Morillas, A.; Ojeda-Benítez, S.; Arango-Escorcia, G.; Cabrera-Elizalde, S.; Quecholac-Piña, X.; Velasco-Pérez, M.; Sotelo-Navarro, P.X. Assessment of gardening wastes as a co-substrate for diapers degradation by the fungus Pleurotus ostreatus. Sustainability 2015, 7, 6033-6045. [CrossRef] 
29. Espinosa-Valdemar, R.M.; Sotelo-Navarro, P.X.; Quecholac-Piña, X.; Beltrán-Villavicencio, M.; Ojeda-Benítez, S.; Vázquez-Morillas, A. Biological recycling of used baby diapers in a small-scale composting system. Resour. Conserv. Recycl. 2014, 87, 2014. [CrossRef]

30. Lam, S.S.; Wan Mahari, W.A.; Ma, N.L.; Azwar, E.; Kwon, E.E.; Peng, W.; Chong, C.T.; Liu, Z.; Park, Y.K. Microwave pyrolysis valorization of used baby diaper. Chemosphere 2019, 230, 294-302. [CrossRef]

31. Itsubo, N.; Wada, M.; Imai, S.; Myoga, A.; Makino, N.; Shobatake, K. Life cycle assessment of the closed-loop recycling of used disposable diapers. Resources 2020, 9, 34. [CrossRef]

32. Takaya, C.A.; Cooper, I.; Berg, M.; Carpenter, J.; Muir, R.; Brittle, S.; Sarker, D.K. Offensive waste valorisation in the UK: Assessment of the potentials for absorbent hygiene product (AHP) recycling. Waste Manag. 2019, 88, 56-70. [CrossRef]

33. Khoo, S.C.; Phang, X.Y.; Ng, C.M.; Lim, K.L.; Lam, S.S.; Ma, N.L. Recent technologies for treatment and recycling of used disposable baby diapers. Process. Saf. Environ. Prot. 2019, 123, 116-129. [CrossRef]

34. Tripathi, G.; Bhardwaj, P. Decomposition of kitchen waste amended with cow manure using an epigeic species (Eisenia fetida) and an anecic species (Lampito mauritii). Bioresour. Technol. 2004, 92, 215-218. [CrossRef]

35. Gupta, R.; Garg, V.K. Vermiremediation and nutrient recovery of non-recyclable paper waste employing Eisenia fetida. J. Hazard. Mater. 2009, 162, 430-439. [CrossRef]

36. Sinha, R.K.; Herat, S.; Bharambe, G.; Brahambhatt, A. Vermistabilization of sewage sludge (biosolids) by earthworms: Converting a potential biohazard destined for landfill disposal into a pathogen-free, nutritive and safe biofertilizer for farms. Waste Manag. Res. 2010, 28, 872-881. [CrossRef] [PubMed]

37. Sangwan, P.; Kaushik, C.P.; Garg, V.K. Vermicomposting of sugar industry waste (press mud) mixed with cow dung employing an epigeic earthworm Eisenia fetida. Waste Manag. Res. 2010, 28, 71-75. [CrossRef] [PubMed]

38. Č́stková, T.; Hanč, A. Change of the parameters of layers in a large-scale grape marc vermicomposting system with continuous feeding. Waste Manag. Res. 2019, 37, 826-832. [CrossRef]

39. Bhat, S.A.; Singh, J.; Vig, A.P. Vermistabilization of sugar beet (Beta vulgaris L) waste produced from sugar factory using earthworm Eisenia fetida: Genotoxic assessment by Allium cepa test. Environ. Sci. Pollut. Res. 2015. [CrossRef]

40. Tran, Q.N.M.; Mimoto, H.; Koyama, M.; Nakasaki, K. Lactic acid bacteria modulate organic acid production during early stages of food waste composting. Sci. Total Environ. 2019, 687, 341-347. [CrossRef]

41. Nova Pinedo, M.L.; Ferronato, N.; Ragazzi, M.; Torretta, V. Vermicomposting process for treating animal slurry in Latin American rural areas. Waste Manag. Res. 2019, 37, 611-620. [CrossRef]

42. Mupondi, L.T.; Mnkeni, P.N.S.; Muchaonyerwa, P. Effects of a precomposting step on the vermicomposting of dairy manure-waste paper mixtures. Waste Manag. Res. 2011, 29, 219-228. [CrossRef]

43. Lei, F.; Vandergheynst, J.S. The effect of microbial inoculation and $\mathrm{pH}$ on microbial community structure changes during composting. Process Biochem. 2000, 35, 923-929. [CrossRef]

44. Kalemelawa, F.; Nishihara, E.; Endo, T.; Ahmad, Z.; Yeasmin, R.; Tenywa, M.M.; Yamamoto, S. An evaluation of aerobic and anaerobic composting of banana peels treated with different inoculums for soil nutrient replenishment. Bioresour. Technol. 2012, 126, 375-382. [CrossRef] [PubMed]

45. Yu, H.; Huang, G.H. Effects of sodium acetate as a $\mathrm{pH}$ control amendment on the composting of food waste. Bioresour. Technol. 2009, 100, 2005-2011. [CrossRef]

46. Barker, A.V. Composition and uses of compost. In ACS Symposium Series; American Chemical Society: Washington, DC, USA, 1997; Volume 668, pp. 140-162. ISBN 13: 9780841235144.

47. Unuofin, F.O.; Mnkeni, P.N.S. Optimization of Eisenia fetida stocking density for the bioconversion of rock phosphate enriched cow dung-waste paper mixtures. Waste Manag. 2014, 34, 2000-2006. [CrossRef]

48. Leme, M.M.V.; Rocha, M.H.; Lora, E.E.S.; Venturini, O.J.; Lopes, B.M.; Ferreira, C.H. Techno-economic analysis and environmental impact assessment of energy recovery from Municipal Solid Waste (MSW) in Brazil. Resour. Conserv. Recycl. 2014, 87, 8-20. [CrossRef]

49. Rabl, A.; Spadaro, J.V.; Zoughaib, A. Environmental impacts and costs of solid waste: A comparison of landfill and incineration. Waste Manag. Res. 2008, 26, 147-162. [CrossRef]

50. Aye, L.; Widjaya, E.R. Environmental and economic analyses of waste disposal options for traditional markets in Indonesia. Waste Manag. 2006, 26, 1180-1191. [CrossRef] 
51. Mihai, F.C.; Ingrao, C. Assessment of biowaste losses through unsound waste management practices in rural areas and the role of home composting. J. Clean. Prod. 2018, 172, 1631-1638. [CrossRef]

52. Bernardes, C.; Günther, W.M.R. Generation of domestic solid waste in rural areas: Case study of remote communities in the Brazilian Amazon. Hum. Ecol. 2014, 42, 617-623. [CrossRef]

53. Kumar, S. Municipal Solid Waste Management in Developing Countries; CRC Press Taylor \& Francis Group: Boca Raton, FL, USA, 2016; ISBN 9781498737753.

54. Ferronato, N.; Rada, E.C.; Gorritty Portillo, M.A.; Cioca, L.I.; Ragazzi, M.; Torretta, V. Introduction of the circular economy within developing regions: A comparative analysis of advantages and opportunities for waste valorization. J. Environ. Manag. 2019, 230, 366-378. [CrossRef]

55. Kim, K.S.; Cho, H.S. Pilot trial on separation conditions for diaper recycling. Waste Manag. 2017, 67, 11-19. [CrossRef] [PubMed]

56. Cordella, M.; Bauer, I.; Lehmann, A.; Schulz, M.; Wolf, O. Evolution of disposable baby diapers in Europe: Life cycle assessment of environmental impacts and identification of key areas of improvement. J. Clean. Prod. 2015, 95, 322-331. [CrossRef]

57. Kim, K.S.; Kim, K.J. Evaluation of a disposable-diaper collection trial in Korea through comparison with an absorbent-hygiene-product collection trial in Scotland. Sustainability 2018, 10, 773. [CrossRef]

58. Thyberg, K.L.; Tonjes, D.J. Drivers of food waste and their implications for sustainable policy development. Resour. Conserv. Recycl. 2016, 106, 110-123. [CrossRef]

59. Hoffmann, B.S.; de Simone Morais, J.; Teodoro, P.F. Life cycle assessment of innovative circular business models for modern cloth diapers. J. Clean. Prod. 2020, 249, 119364. [CrossRef]

60. Mendoza, J.M.F.; Popa, S.A.; D’Aponte, F.; Gualtieri, D.; Azapagic, A. Improving resource efficiency and environmental impacts through novel design and manufacturing of disposable baby diapers. J. Clean. Prod. 2019, 210, 916-928. [CrossRef]

61. Mendoza, J.M.F.; D’Aponte, F.; Gualtieri, D.; Azapagic, A. Disposable baby diapers: Life cycle costs, eco-efficiency and circular economy. J. Clean. Prod. 2019, 211, 455-467. [CrossRef]

(C) 2020 by the authors. Licensee MDPI, Basel, Switzerland. This article is an open access article distributed under the terms and conditions of the Creative Commons Attribution (CC BY) license (http://creativecommons.org/licenses/by/4.0/). 